\title{
ON BEING HEARD BUT NOT SEEN: MILBANK AND LASH ON AQUINAS, ANALOGY AND AGNOSTICISM
}

\section{PAUL DEHART}

\section{Introduction}

The phrase "radical orthodoxy" deliberately connotes a two-fold gesture: on the one hand, a self-consciously radical critique of (what is purported to be) "modernity" which owes much to contemporary philosophical developments; on the other hand, a re-reading of selected figures of the classical Christian tradition which seeks to locate within them the proleptic presence of this same critique. ${ }^{1}$ It cannot be assumed that these twin maneuvers readily harmonize, and it is to the credit of those who work within the ambit of this thought-world that they have offered the scholarly public detailed interpretations of great theologians of the past as support of their reading of the present intellectual challenge facing theology. ${ }^{2}$ The founding intellectual gestures of the disastrous modern epoch will thus, with a certain precision, map inversely onto the root ideas of classic orthodoxy; hence, a return to radical Christianity coincides with a radical critique of the modern. Or so the theory goes. The cogency, indeed the very coherence of the sweepingly ambitious claims associated with this intellectual tendency will thus rest, to a significant degree, on the plausibility of those historical essays. The following will attempt a modest critical contribution to this question by examining John Milbank's interpretation of Thomas Aquinas on analogy and knowledge of God in the central chapter of Truth in Aquinas. ${ }^{3}$

That book (written in collaboration with Catherine Pickstock) marked Milbank's most sustained attempt to lay claim to the great scholastic doctor as a "radically orthodox" forerunner. The second of four chapters, "Truth and 
Vision" is the longest, most complex, and most challenging take on Aquinas in the book, and is arguably the conceptual heart of its interpretive enterprise. It also represents Milbank's most extensive engagement with Aquinas's actual texts by far (some 192 citations of his writings), though the reader expecting a chapter structured as a sustained conversation with passages or arguments of Aquinas will find herself instead following multiple discontinuous and overlapping threads of assertion in accord with the author's dazzlingly idiosyncratic agenda. Indeed some readers will be unable to shake the feeling that the claims made here could hardly have arisen from any straightforward reading of Aquinas. The unseen force shaping the way this reading of Aquinas unfolds is in one sense, no doubt, the program of "radical orthodoxy" itself; but on a more immediate level a vital exegetical clue to this chapter is that its final form is marked by a certain damnatio memoriae. For to a large degree this chapter was originally written in vigorous debate with another theologian; in the transition to book form the arguments themselves were kept virtually intact, while, in a manner reminiscent of the systematic effacement of infamous names from Egyptian monuments, Milbank excised almost every mention of the person against whom those arguments were directed. Although the distinctive voice of Nicholas Lash can still be heard echoing through Milbank's counter-arguments, Lash's face, so to speak, is no longer seen. ${ }^{4}$

This article will attempt to do three things at once. It will lay out one of Milbank's large and controversial claims about Aquinas in "Truth and Vision" and offer an archaeology of the prior polemical context out of which the claim arose: for Milbank in that chapter asserts that the doctrine of analogy in Aquinas is peculiarly implicated with his entire ontology, a thesis whose meaning and purpose are illuminated once it is seen as the vigorous repudiation of a "grammatical" or "linguistic" interpretation which had been proffered long before by Nicholas Lash (following Herbert McCabe and David Burrell). At the same time, the article will provide a close investigation of the citations and interpretations of Aquinas that Milbank uses to ground his position, in order to adjudicate the dispute with Lash. The result will be to call strongly into question the plausibility of Milbank's readings of Aquinas. Finally, the article will indicate at several points the way in which those readings seem to be driven and, it will be suggested, distorted by an overriding anfi-Kantian thrust in Milbank's entire approach to the discussion.

The first of the two main sections will provide a narrative of the earlier disagreements between Lash and Milbank on Aquinas which led up to "Truth and Vision" in order to situate the original context of Milbank's claims about analogy and offer some preliminary assessments. The second will turn to a critique of the more elaborated version of Milbank's argument in "Truth and Vision." The article's conclusion will adumbrate a larger and older question which subtends the entire dispute, though it remains for the most part 
implicit: "To what degree is some kind of vision or intuitive grasp of being as such, or of God's being, granted human beings in this life?"

\section{Origins and Development of the Dispute over Aquinas}

\section{Is there an Intuition of being? MacKinnon and Lash on Analogy in Aquinas}

In many ways this story, like much that is most interesting in recent theology in England, begins with Donald MacKinnon. ${ }^{5}$ The towering, eccentric Scotsman (no Presbyterian but rather a member of the Episcopal Church of Scotland, a Catholic in ecclesial and theological outlook) held the Norris-Hulse chair in Cambridge for almost twenty years. As he threaded his life's path of agonizingly self-aware dissent over the course of the bloody twentieth century, he launched one attempt after another toward a contemporary retrieval of the implicit ontology of Nicaea and Chalcedon, always faithful to a creatively Kantian ethic of the limits of cognition, and deeply colored by his bruisingly intimate feel for the irredeemability of historical suffering. This (for its time) highly atypical theological stance challenged and intrigued any number of independent thinkers, especially at Cambridge, as did his tireless recommendations of Barth and Balthasar in a period of Anglican theology when the first was far from popular and the second hardly known. Nicholas Lash was called to be his successor to the chair in 1978; repeatedly acknowledging MacKinnon's influence, Lash naturally contributed an essay to the volume honoring MacKinnon which appeared in 1982.

In "Ideology, Metaphor and Analogy" Lash discussed the interplay in religion and theology between the dimensions of "construction" and "discovery" constitutive of human knowing. ${ }^{6}$ The ineradicable moment of imaginative projection and creativity in all human knowledge needs to be continually checked against the hard surfaces of intractability and resistance to meaning to be found in the encounter with reality; only this balance will prevent the slide of religion into ideology. Although in this subtle treatment Lash was honoring MacKinnon by drawing upon some of his characteristic themes, he also ventured a correction of his predecessor on the issue of analogy. ${ }^{7}$ Lash proposed a metaphysical analysis of the limits of human discourse in face of the divine as not in itself capable of generating a positive "doctrine" of God suitable for religious life and worship, but nonetheless as an important critical check upon the creative exuberance of poetic religious language. Lash defined metaphysical analysis as an exploration of "analogical usage of unrestricted generality"; it focuses on the possibilities and limitations of the most general categories available to human thought, those concepts presupposed in all rational discourse. ${ }^{8}$ As far as speech about God is concerned, metaphor provides the original, rich medium of praise and prayer; but only the possibility of analogical predication about 
God (affirming a literal dimension of meaning, unlike metaphor which is premised upon its denial) allows theology a critical tool to anchor religious speech, a precaution against the drift of a religious community's "projective" self-narration into delusive fantasy.

In this appeal to the indispensability of analogical language in theology, Lash had to address the skepticism of MacKinnon himself. The latter's reliance early in his career upon an account of analogical knowledge along broadly scholastic lines gave way to sharp doubts as to the ability of analogy to allow positive assertions about God in the wake of Kant's critique of knowledge. ${ }^{9}$ The analogical "device [of the scholastics] for allowing assertion on the basis of negation demands assumptions that we cannot make. For we would have to admit in knowledge a kind of intuitive awareness of analogically participated being which we do not seem to have. ${ }^{10}$ The future dispute between Milbank and Lash pivots on Lash's response to MacKinnon on this issue.

Relying closely on David Burrell's treatment of Aquinas on analogy, Lash insists that attending carefully to the work of Aquinas himself (as opposed to the generalized scholastic consensus which arose in the centuries after his death) will reveal that he did not, in fact, see in analogy a way of transcending apophatic critiques of our God-language, an "end run" toward positive knowledge (MacKinnon's "allowing assertion on the basis of negation"). ${ }^{11}$ Nor does Aquinas's use of analogy presuppose any special intuition of being. He rather directs our attention to an important semantic characteristic of those perfection-terms licensed by scripture and used by believers of God: "good," "wise," and the like are concepts whose range of meaning extends fuzzily across a variety of distinct contexts of use which are incapable of exhaustive enumeration, and herein lies the linguistic possibility of their literal (as opposed to metaphorical) reference to things which transcend our limited mode of knowing.

The possibility of such an application specifically to God lies in the metaphysics of creation with which Aquinas worked, locating all creaturely perfections in God. As cause of creatures, God pre-possesses any real excellences they display, albeit "in a more eminent fashion" (i.e., in the unfathomably singular mode of the divine essence itself). Given this ontological assumption, one can interpret perfection-terms drawn from creaturely experience, if they already display a range of meaning which does not directly connote creaturely limitation, as in fact analogically picking out features of the created order which are inferior shadows or reflections of God's properly unimaginable perfection. Thus to call God "good" is not a metaphor (such as calling God the "rock" of salvation), since our grasp of the attribution does not require a concomitant understanding of its literal inapplicability. Lash wishes to make a twofold point on the basis of this discussion. First, analogy in Aquinas is part of a metaphysical analysis of the grammar of our conceptual speech which draws attention to the careful delimitations always implicit in 
religious speech about God; it in no way builds up a positive philosophical picture of divine attributes based on a gymnastic dialectic, but serves to discipline and specify that living intercourse with God which happens in communal worship. Second, it consequently does not make appeal to some primal, special mode of knowledge or intuition. Thus analogy (in Aquinas at least) is not complicit with the threat of religious self-delusion, as MacKinnon feared, but is properly a precaution against that threat.

\section{Milbank's (Covert) Riposte}

Four years after the appearance of Lash's essay, in July 1986, a conference was held at Cambridge honoring the work of MacKinnon. One of the papers delivered there, remarkable for its density and scope, was by 33-year-old John Milbank, just completing his doctorate and not yet occupying a permanent teaching post. ${ }^{12}$ Dealing with the issue of the pernicious and persistent influence of Kantian metaphysics (and its concomitant social vision) in Christian theology, the paper began by complaining of a tendency on the part of some theologians to assimilate what should be most sharply distinguished: Aquinas's account of the limitations of our knowledge of God, and Kant's account of those limitations. ${ }^{13}$ There is something curious about this discussion. Just four years earlier, Nicholas Lash, in the context of critically honoring Donald MacKinnon, had invoked the work on Aquinas of Herbert McCabe and David Burrell in order to insist that analogy should be understood primarily in terms of the conceptual grammar of certain linguistic usages. ${ }^{14}$ Now, in his paper, Milbank, in the context of critically honoring Donald MacKinnon, specifically condemns the work on Aquinas of Herbert McCabe and David Burrell in order to insist that analogy cannot be understood primarily in terms of the conceptual grammar of certain linguistic usages. Milbank had read divinity at Cambridge a few years earlier, and was quite familiar with Lash and his work, and yet somehow Lash's name is not once mentioned in Milbank's paper. ${ }^{15}$ But no informed person who heard it could fail to grasp that it contained an attack directed squarely against the reading of analogy and Aquinas which Lash had laid out in his 1982 essay. Although differing in a number of details from his discussions of this same theme in "Truth and Vision," Milbank's account here nonetheless adumbrates some of the key themes of that chapter. Because of this, and due to the inherent difficulty of Milbank's argument, treatment in some detail is called for.

In arguing against Burrell's (and by implication Lash's) understanding of Aquinas on analogy, Milbank characteristically offers multiple considerations, closely connected and often overlapping. For purposes of evaluating his criticism, three threads can be loosely distinguished: the position attributed to Aquinas by Burrell is basically Kantian; it is anachronistic; and it is not true to the way Aquinas conceives the relation of language to reality. 
(i) Milbank's critique: covert Kantianism?

As Milbank reads Kant, the absolute strictures on the application of basic concepts like "cause" which the critical philosophy introduced, i.e., their strict limitation to possible objects of experience (and thus their inapplicability to the "noumenal" realm, including God) were grounded in a merely dogmatic anthropology of cognition. Only by locating the "real" human subject itself within the noumenal realm could Kant argue that a purely rational critical self-inspection of human cognitive capacities is possible, one that is able not merely to gesture toward the limits of human thought, but to assign it a precise boundary, and to determine the respective contents of the realms on either side of the boundary (phenomena and noumena). Only the noumenal Kantian self is in a position to "see" the frontier between phenomena and noumena, the frontier which is presupposed by the limit of categories to the realm of possible schematization, because in some sense it already stands on both sides of that frontier. ${ }^{16}$

Milbank's first complaint against Burrell's reading is that the very idea that Aquinas could analyze our words in order "to indicate the range of possible meanings available to us in our finitude, and by this operation to show, indirectly, what terms cannot apply beyond our finitude" makes Aquinas a forerunner of Kant's position. ${ }^{17}$ Milbank claims that Burrell is thereby in fact joining a larger trend, of which Herbert McCabe provides the most ready example, whereby "a post-critical confinement of analogy to 'our use of language', detached from questions of participation in Being" is linked to an affirmation of the "analogy of attribution" as basic to Aquinas's doctrine of analogy. ${ }^{18}$ But this (justified) rejection of the late scholastic privileging of the "analogy of proportionality" as well as the (questionable) demotion of analogy in Aquinas to a linguistic or grammatical (as opposed to ontological) concept are both driven by the same, covertly Kantian impulse: to interdict any proper knowledge of God's being and thereby offer up a kind of "agnostic" Aquinas. But, Milbank asks, does this not make the inherent capacities of language into a kind of Kantian transcendental framework determining theological possibilities a priori?

This is a curious sort of criticism. In their interpretations of Aquinas on analogy, neither McCabe, nor Burrell nor Lash make appeal to Kant, or show any interest in drawing a parallel between Kant's limits to cognition and those of Aquinas. Milbank, indeed, thinks he sees a degree of overlap between their descriptions of Aquinas and his own rendering of Kant's position; but to frame the discussion as a battle against covert supporters (or unwitting dupes?) of Kantianism is a tendentious distraction from the task of engaging their actual arguments, which are based exclusively on texts of Aquinas. At any rate, the conclusion he draws from the perceived parallel with Kant, namely that this "cannot" be Aquinas's position, lacks compelling warrant. First Milbank says that to be consistent these thinkers should, like Kant, really privilege the "analogy of proportionality;" but that would only be 
the case if their readings actually shared the logic of Kant's agnosticism, which cannot be assumed. ${ }^{19}$ Second he says that Kant's "straddling the boundary" of the knowable and unknowable is a philosophical move which postdates Aquinas; again, this simply presupposes that the only rationale for demarking the limits of human speech vis-à-vis God must be the Kantian one which he outlined earlier.

(ii) Milbank's critique: an incorrectly "updated" Aquinas?

While Milbank's first move of simply identifying Burrell's reading of Aquinas with Kant's transcendentalism rather begs the question, his second line of critique is more to the point. Milbank tries to show that the specific way Burrell reads Aquinas relies upon the importation of ideas into his world of thought which only arose later in the medieval period. The first anachronism is that it is only Duns Scotus who "uses grammar in a 'quasi-foundationalist' way to delimit the scope of certain meanings prior to their employment in theology. ${ }^{120}$ But several considerations vitiate the force of this objection. First, presuming for a moment that this is an adequate description of what Burrell attributes to Aquinas, Milbank offers no support for his claim that Scotus was the first to do this sort of thing. Second and more generally, it is doubtful that any kind of appeal within a theological argument to the semantic and conceptual range of linguistic usage in general automatically renders one guilty of trying to "ground" theology on some immediately and universally accessible base, as the charge of foundationalism implies. At any rate, the reader will have to withhold judgment until she sees how Milbank deals with the text of Aquinas which Burrell cites in support of his understanding. Milbank's assertion that Aquinas cannot be "us[ing] grammar ... to delimit the scope of certain meanings" of words used in theology won't carry much weight if one catches Aquinas doing just that.

The second anachronism Milbank finds in Burrell concerns the latter's seeing in Aquinas's argument certain moves, especially regarding the distinction between "thing signified" and "mode of signification," which in fact belong to the "speculative grammar" of the so-called "modists" who flourished in the decades after Aquinas's death. ${ }^{21}$ However, not only does Burrell not use the technical term "speculative grammar," but an examination of the way he understands Aquinas's use of the concept of "mode of signification" suggests a reliance only on the rather straightforward sense of the idea which had been in wide usage long before Aquinas's day. The technical elaborations introduced by Martin of Dacia and the other modists in the 1270s (precise enumeration of the "modes" and their mapping onto a set of ontological correlates, etc.) is nowhere in evidence in Burrell's treatment, which instead divines Aquinas's usage based on the context of actual passages in his text. Hence it is not really relevant when Milbank then goes on in a detailed footnote to show that Aquinas and the modists understood the meaning of "mode of signification" differently, since he has not shown that Burrell's 
argument turns upon the modist understanding. The topic does, however, issue in the third and most substantive strand of Milbank's criticism: in his reading especially of the crucial text ST I q13 a3, Burrell has attributed an understanding of language, reference and reality which is quite foreign to Aquinas.

(iii) Milbank's critique: linguistic foundationalism?

A series of claims about the positions on this matter of both Burrell and Aquinas are made or suggested by Milbank; rather than risk distorting them by trying to situate them within some overarching theoretical position, it will be safest (though laborious) to evaluate them piecemeal. The discussion really turns on just what Aquinas means in making the following claim: when names of creaturely perfections like "good" or "living" are used of God, what they signify befits (convenit) God properly (not metaphorically), but their mode of signification befits only creatures. ${ }^{22}$

First, it is a little too crude when Milbank says that Burrell's interpretation of this distinction allows "grammar" alone to "show ... what terms cannot [and those which can] apply beyond our finitude." ${ }^{\prime 23}$ Strictly speaking, this confuses two issues. The distinction drawn in the body of Aquinas's reply between "what" is signified by a perfection term and its "mode" does not directly concern which terms can or cannot apply to God. The previous article (ST I q13 a2) has already identified a class of terms, those designating creaturely perfections, which can be said to refer to God's very substance (as site of all creaturely perfections in an eminent mode). The current article (q13 a3) is concerned only to further affirm that the perfections named by such terms belong to God properly and not metaphorically, even though the meanings actually involved in any human reference to those perfections are proper only to finite creatures. It might be helpful here to recall that "to signify" in the usage inherited by Aquinas is a causal term; a person uses a word in accordance with the idea she has in her mind, and this word when grasped by another mind causes the same idea to present itself there. ${ }^{24}$ The mode or manner of signification refers to the actual mental contents annexed to the word as uttered or understood, which may or may not accord adequately with the reality to which the word refers.

A moment's consideration of this will bring the realization that Aquinas's use of the distinction in $\mathrm{q} 13 \mathrm{a} 3$ opens the door to literally true discourse about some reality even where adequate knowledge of that reality is lacking, which is precisely Burrell's point. Aquinas, as he reads him, is insisting that the ability to make a true and non-metaphorical predication concerning God in no way implies proper knowledge of God on the part of the one making the predication. Milbank is repelled by the implications of this, but it is not hard to point to a similar, less controversial instance in Aquinas of this kind of distinction. In insisting that the existence of God has to be demonstrated, Aquinas admits (ST I q2 a1) that "in itself" the proposition "God exists" is 
self-evidently true, but denies that it is self-evident "to us." Even though our intellects can and must affirm that the grammar and meaning of the proposition meet the logical requirement for self-evidence (because we can demonstrate that God's essence and act of being are identical, ST I q3 a4), in this life we nonetheless must fail to understand this self-evidence, to "see" the logical necessity of it, because we cannot know either God's essence or God's act of being. In the same way, when we use perfection terms of God our intellects can and must affirm that the perfections named more fully befit God than creatures, but we can no more "see" or grasp how this is so than we can see or grasp how God's essence is identical with God's act of being. We know that God is the highest good, but we can know only worldly goods.

So the distinction Aquinas draws between "what is signified" and our "mode of signifying" is not concerned with what terms can and cannot apply to God, but with the logically distinct issue of what such application, once granted, implies about knowledge. However, there is a closely connected discussion in Aquinas which does indeed concern finding a semantic marker which distinguishes words capable of the kind of proper signification being discussed from those which can only signify metaphorically. It is perhaps this discussion which Milbank has in mind in his characterization of Burrell, but he is mistaken to link this to the "thing signified" / "mode of signifying" distinction. In the reply to the first objection at q13 a3, Aquinas points out that only those terms are available for proper or non-metaphorical predication of God the significations of which do not include the deficient manner in which a creature participates the creator's perfection. Hence the term "rock" signifies a perfection (it is something existent, and existence is a perfection), but its definition signifies substantive existence only as relative to a mode of creaturely participation (i.e., as material or enmattered existent). Terms like "existent" itself, on the other hand, and "good," and "living," are so defined that they signify perfections absolutely, not relative to their mode of participation. Note carefully that this differentiation does not involve the "thing" / "mode" distinction at all. A rigorously limited mode of signification applies to both a term like "rock" and a term like "good"; but the positive idea of creaturely limitation is built into the very definition of "rock" in a way that is not the case with the definition of "good."

The point of this discussion has not been to delineate Burrell's full argument, which involves some complexities not touched on here; the point rather has been to defend it from Milbank's criticisms. It is hard to see from what has just been said why Burrell's "grammatical" account of Aquinas is not perfectly justifiable. When Aquinas goes on after this (q13 a5) to clarify how terms are predicated of creatures and of God not univocally but analogically, the semantic distinctions discussed in article 3 are presupposed: it is precisely names like "good" and "wise" which are available for analogical predication, subject to the constraints of signification and mode of signification already laid down by Aquinas. And, contrary to Milbank's wording, 
at no point is the issue the Kantian one of which terms can meaningfully and rationally be applied to God. For Burrell and Aquinas many terms, whether springing from scripture, tradition or the sanctified imagination, can be said of God both meaningfully and rationally. The issue is, rather, which terms can be said to apply literally as opposed to metaphorically.

\section{Milbank's Alternative Aquinas}

More questions arise when Milbank, in some of his most difficult and surprising remarks, goes beyond criticism of Burrell's own position to suggest, at least in outline, his own alternative account of Aquinas's idea of language. Indeed the heart of his disagreement with Burrell's reading seems to be that the constraints of our "mode of signifying" cannot determine the possible senses or meanings of words because, on Aquinas's understanding, "sense derives mainly from the object of reference" (and thus not, presumably, from our linguistic usages).$^{25}$ As a general claim it is hard to fathom how Aquinas could be construed this way. Does sense or meaning here mean "what a word refers to?" But it has already been seen that for Aquinas the issue of reference (what we can talk about) must be distinguished from the issue of signification (what we can understand in so doing). Hence sense or meaning must refer to signification. But then how can it be said that our mode of signifying doesn't determine the human possibilities of meaning when it is Aquinas's consistent position that words connect with the things they signify only as mediated by the user's intellectual conception (ST I q13 a1)? Further, what can it mean to say that the sense of a word derives from the object of reference? It would seem that Aquinas's position is rather that lexical meanings derive from the human "imposition" of the word (ST I q13 a2 ad2), whereby a given word arises from some primitive etymological association ("imposition from") but is assigned a semantic range according to human intentions become conventional usage ("imposition to"). How is this picture to be accommodated to the idea of some kind of communication of "meanings" from objects of reference to the words referring to them?

The general picture of the origin of meaning which seems to lie behind Milbank's brief remark surely causes more difficulties for interpreters of Aquinas than it solves. But perhaps his thinking is guided by a special case, that of reference to God. This is suggested by his claim that when God is the object of knowledge, then "the mode of being and sense of the thing known ... constitutes the existence of, and meaning available to, the knowing subject." ${ }^{26}$ In this particular situation it is no doubt true that God causes the being of the human knower, and thereby also causes the being of the mind and its ideas. But Milbank apparently concludes from this that the possible range of meanings of the ideas and words used about God are determined ("mainly"?) from the direction of the object referred to, and therefore not from the inherent limits of the human knower. The conclusion does not follow, however, and anyway could hardly avoid coming into conflict with a 
principle which Aquinas repeatedly affirms: "The thing known is in the knower according to the mode of the knower" (e.g. ST II/II q1 a2). The entire discussion of ST I q13 only makes sense against the background of this basic tenet; words refer to things only as the latter are grasped in human intellects, hence anything is named by us only as grasped by our intellects (ST I q13 a1), and thus (ad2) "the names which we attribute to God signify only in a manner proper to material creatures, knowledge of which is natural to us."

Milbank, too, adverts to the point made in q13 a1 about the interrelation of words, ideas and things, though he draws quite a different conclusion about how words can refer to God than the one suggested by the quoted reply to the second objection. Indeed, starting from the unique way he reads that interrelation one can sum up what seems to be Milbank's overall counterposition with regard to McCabe and Burrell, isolating three basic points.

The first point is that analogy in Aquinas cannot be understood in semantic or grammatical terms, but is already inextricably included within his ontology of creaturely participation in the creator. Of course, McCabe, Burrell and Lash all point out that analogical reference to God in Aquinas only works because of just this creaturely participation. But they also insist that this is a necessary but not sufficient condition for such reference; there must also be certain highly general concepts in which linguistic usage has encoded an indeterminable semantic range, these being precisely those perfection-terms free of any denotation of finite limitation already mentioned. Against this Milbank brings forward his own alternative reading of the quote from q13 al: because "[s]igns, for Aquinas, reflect ideas, which ... reflect existing realities" he could not have ceded any force to arguments drawn from some quasi-discrete realm of linguistic usage, since the semantics of words must already be caught up within a particular metaphysical account of things. ${ }^{27}$ Against this, first, one can point back to the course of the argument above, which suggests that Aquinas is indeed doing what Milbank says he cannot do; second, one can suggest that the key to interpreting the chain "thingidea-word" lies in the crucial middle link. Words accord primarily with our ideas, but our ideas in turn reflect things only under the conditions of human knowledge, and this is precisely why there can and must be for Aquinas a determination of patterns of semantic possibility which is in principle distinct from considerations of the structure of the real order of being. Meaning is one thing, metaphysics another.

But what are the conditions of human knowledge in their grasp of things? Milbank's answer to this question marks the second point of his position, for he evidently has in mind some picture of the cognitive relationship between human minds and created things which, rather than forbidding proper knowledge of their creator (the position of Burrell et al., and arguably the intention of many of Aquinas's statements), positively implies such knowledge. This striking epistemological picture is hardly developed in Milbank's paper, but seems to be presupposed in his reading of a quote like 
the following: "God is called wise not only as what causes wisdom, but because as we are wise we to some degree imitate his power, by which he makes us wise" (SCG I 31 [2]). Rather than seeing the point of this utterance to be just the same as was argued for above, namely that naming God wise involves affirming our own deficient imitation of a perfection eminently contained in its cause, Milbank chooses to read it this way: "The degree to which [our naming God by a perfection-term] is not a purely empty attribution is precisely the degree to which one thereby conceives, and personally enters into, the dynamic of created being. ${ }^{\prime 28} \mathrm{He}$ apparently means that God's goodness, say, cannot be simply affirmed but strictly speaking unknown (as Burrell would have it); rather, affirming goodness of any creature involves the human mind in a dynamism whereby a certain implicit grasp of the creator's goodness itself is already implicated precisely in apprehending the creature's mode of goodness as one of deficient participation. An implication of this brief suggestion, one which will be seen to undergo considerable later development at Milbank's hands, is that for Aquinas knowledge of things and knowledge of God are in every case mutually implicated.

The third aspect of Milbank's proposal is the explicitly anti-Kantian thrust which suffuses the entire course of the argument and drives the readings of Aquinas on both of the first two points. Thus, first, analogy cannot be primarily grammatical because that implies a "general" framework of meaning unstructured by prior theological commitments which nonetheless must be acknowledged by the theologian. Is this not, asks Milbank, too close to a kind of neutral, purely rational articulation of the possibilities of cognition of God such as Kant undertook in his transcendental analysis of knowledge? Second, the "agnostic" limiting of proper knowledge to created perfections only, leaving them to be affirmed of God but not known in God, imitates the Kantian gesture of affirming a static boundary between phenomenal and noumenal realms, with knowledge immanently confined to the former. ${ }^{29}$

Though a lengthy analysis has now been devoted to a section of Milbank's 1986 conference paper, it will turn out to be amply justified by the highlighting of these three aspects of Milbank's approach to Aquinas. The denial of a "grammatical" or linguistic reading of analogy, the removal of any firm epistemic boundary between creatures and creator in order to affirm their cognitive co-implication, and the anti-Kantian affect motivating both of these moves, collectively lay down the lines of the developing dispute with Nicholas Lash. They also adumbrate the dominant themes sounded in "Truth and Vision" fifteen years later. To see how this is so, the thread of the narrative with which this section began must be taken up again.

\section{The Sudden Resurrection of the Lash-Milbank Dispute}

If Milbank's 1986 paper was indeed, as appears to be the case, an attempt to refute Lash on Aquinas without naming him, the indirect provocation 
initially met with no public response from the latter. Instead, as the years passed Lash found much to praise in Milbank's growing body of work, and was obviously especially impressed by the publication of Milbank's grand statement on Theology and Social Theory, which occurred in 1990, the same year that Milbank returned to Cambridge to teach theology alongside Lash. In 1992, Lash was one of the contributors to a symposium on Milbank's book in Modern Theology. ${ }^{30}$ His subtle critical probings (against a confessed background of broad agreement) did not touch on the issues raised by Milbank six years earlier, though he does engage Milbank in close textual argument over a passage in Aquinas concerning peace and virtue. ${ }^{31}$

For his part, Milbank during the same period did not return to develop his earlier claims about Aquinas. But even so potential tensions were, in less obvious ways, building up around his interpretations of Aquinas and other "classic" figures, and the stakes seemed to be getting higher. As publications continued to appear which clarified the scope of Milbank's theological vision, its totalizing ambitions were growing ever more radical even as its rhetorical intolerance for perceived rival approaches sharpened apace. Startling pronouncements multiplied, almost always accompanied by appeals to pre-modern Christian thinkers, albeit interpreted in novel and, to many observers, paradoxical ways.

Some examples, with regard to Aquinas in particular: a 1988 paper announced that, far from relying upon a substance metaphysic, the former was actually engaged in a dismantling of its centrality, a "theological metacritique" of the notion; a passage in Theology and Social Theory remarked, almost in passing, that for Aquinas "all knowledge implies faith," destabilizing any firm distinction of revealed and natural knowledge; several years after that a 1995 essay suggested that in Aquinas every intellectual grasp of truth must fuse together a will to the good and an aesthetic judgment of the beauty of intellect's object. ${ }^{32}$ All of these elements would later, in "Truth and Vision," be combined into a highly complex, ramified and very unexpected account of Aquinas's epistemology. ${ }^{33}$ More remarkable still, another essay from the same year criticizing the thought of Jean-Luc Marion aggressively asserted that any merely philosophical metaphysics is ipso facto the enemy of a genuine Christian ontology, and must be theologically divested of any claimed access to being ("evacuated," in the soon notorious phrase); yet again, none other than Thomas Aquinas was invoked as authority for this bold pronouncement. ${ }^{34}$ With this last affirmation from 1995, all three of the major components (including the new account of Aquinas's epistemology and the earlier denial of any merely "linguistic" analogy) of Milbank's eventual large-scale construal of Aquinas in "Truth and Vision" had been put in place, at least in a preliminary way. But it would seem that it was an outside challenge which finally precipitated their more extensive development and unification: in 1997 Nicholas Lash decided, quite publicly, to throw down a gauntlet on the whole issue of Milbank as an interpreter of Aquinas. 
The occasion was a November 1997 meeting of the so-called "D society" at Cambridge, a fortnightly seminar on philosophical theology which MacKinnon had chaired in his years as Norris-Hulse professor, and which was now under the leadership of his successor. An overflow crowd pointed to the keen sense of anticipation with which this particular meeting of the seminar was awaited: it was known that the chair himself was going to deliver the paper (in honor of his twentieth year heading the meeting) and that it was going to take issue with Milbank, who was in attendance. ${ }^{35}$ Five years earlier Lash's criticisms of Milbank were delicately delivered: the latter's reading of Aquinas "seems to me not quite right." Now, however, the paper's memorable opening line registered a rather different tone: "In this short paper, I am going to be rude about John Milbank." ${ }^{\prime 36}$

The paper which followed presented a brief but highly pointed list of complaints, an irreverently worded catalog of sins against scholarship. All three of Milbank's controversial positions on Aquinas outlined above (the gestures toward a revisionist epistemology, the putative rivalry of metaphysics and theology, and the rejection of analogy as primarily a matter of language) were touched upon, and the latter two especially were stingingly dismissed. The concern of the present discussion, of course, is with the last of the three. For it was in this address that Lash finally broke a long silence on Milbank's treatment of McCabe and Burrell on Aquinas and analogy. Milbank, Lash argued, was flatly wrong to accuse Burrell's "grammatical" reading of a quasi-Kantian transcendentalism; defining ontology as conceptual scrutiny in no way separates it from questions of being or participation, but rather directs our attention to the ancient distinction between discourse about things and discourse about discourse; in short, understanding analogy in Aquinas to be more a matter of linguistic rules than of metaphysics simply does not represent an attempt, as Milbank had accused, to "ground theology in grammar. ${ }^{\prime 37}$ Although the constraints of an orally delivered paper denied Lash the opportunity to engage in much detailed exegetical argument, his verdict was clear and uncompromising: Milbank's fanciful claims are bolstered by readings of Aquinas that are either careless or tortured.

Lash's rebuke, astringently worded and delivered in open forum, was deliberately provocative; Milbank did not shy away from the challenge. Indeed, by the time Lash's short but sharp outburst found its way into print two years later, it had clearly awoken an avalanche of a response: over fifty pages of exceedingly dense prose, including ten pages of endnotes, appeared in Modern Theology under the title "Intensities." Ostensibly, Milbank's article (as part of the journal's symposium on his recently published volume of collected essays) was in response to three critical reviewers, of which Lash (whose "D society" paper was printed virtually unchanged) was only one. However, although he claimed that he found the questions of the other reviewers (Wayne Hankey and Frederick Bauerschmidt) more acute, he satisfied himself with relatively brief and unruffled responses to their 
concerns. ${ }^{38}$ The overwhelming bulk of the article is in fact devoted to substantiating Milbank's picture of Aquinas on analogy and metaphysics, thus in Milbank's words "rebutting [Lash's] charges against me" and unmasking his interpretation of Aquinas as hobbled by a "residual liberalism" and a "residual ... neo-thomism. ${ }^{\text {" }} 9$

Milbank's article might be seen as a massive attempt to end the dispute with Lash once and for all by appeal to a truly impressive array of Aquinas texts. As has already been mentioned, he was satisfied enough with the results that the essay appeared two years later as the chapter "Truth and Vision" in his and Pickstock's collaborative volume on Aquinas. Shorn of some explicitly polemical paragraphs at the beginning and end, the text remained, with minor exceptions, identical to "Intensities." Milbank may have carefully expunged his name, but the chapter remains undeniably an artifact of the dispute with Lash. On the matter of Aquinas and analogy, it continued the attack on Lash's "linguistic" interpretation which had been begun in 1986, only on a larger scale and with appeal to a broader array of Aquinas texts. The remainder of this article will therefore take up this material in order to encompass the aims mentioned at the outset: critically evaluating Milbank's appeals to Aquinas, and delineating their polemical matrix in order to understand and assess the dispute with Lash on analogy.

As for the third aim initially announced, that of foregrounding the antiKantian impulse animating Milbank's position and his readings of the texts, the task is made more difficult by the much more sweeping and complicated analysis of Aquinas on offer in "Truth and Vision." But as a beginning Milbank's just cited accusation that Lash's Aquinas is at once too "liberal" and too "neo-Thomist" should not pass unremarked. The point is that Lash's whole way of approaching Aquinas supposedly relies upon a dubious juxtaposition of theological knowledge based on revelation or faith and a "foundational" ontology which claims to be theologically neutral. It is just this dualistic separation of theology and metaphysics which, Milbank says, characterizes the "baroque" scholastic framework of neo-Thomism and "liberal" Catholic positions associated with Lonergan, Rahner and transcendental Thomism. Later comments from "Intensities" make crystal clear that this verdict is really a way of flushing out the Kantian specter lurking, Milbank is convinced, behind Lash's position on analogy: his "transcendentalist" appeal to mere "grammar" as the ground of possibility for analogy is premised, just like "Baroque metaphysical rationalism," upon "the sundering of metaphysics from sacra doctrina" which "is inevitably fulfilled in metaphysics-asepistemology before and with Kant." ${ }^{\prime 40}$

\section{Aquinas on Analogy in "Truth and Vision": Language or Ontology?}

To reiterate, much of the sixth section of "Truth and Vision" (pp. 43-51) amounts to a far longer and more elaborate argument for the stand Milbank 
took against McCabe, Burrell and (implicitly) Lash in his 1986 paper: their interpretation of analogy in Aquinas as predominantly a matter of understanding possibilities of linguistic usage must be proven false. The discussion can be analyzed into three components. First, Milbank tries to explain what is theologically questionable about an understanding (like Lash's) of metaphysical inquiry in general as primarily grammatical in character. Next, Milbank offers some passages of Aquinas which he thinks prove that analogy in Aquinas is chiefly concerned with ontology, not with language. Finally, he gives some indication of the metaphysical assumptions upon which, in his opinion, Aquinas bases his discussion of analogy.

\section{What Is Wrong with Metaphysics as "Grammatical"?}

Milbank's complaints about Lash's conception of ontology, though highly revealing of his own understanding of how theology should conceive of such an enterprise, are hampered by what seem to be misconstruals of Lash's position. It will be recalled that Lash, as did MacKinnon before him, finds illumination in the philosopher Peter Geach's portrayal of ontology: "Certain concepts, like existence and truth and thing and property, are used, and cannot but be used, in all rational discourse whatsoever; and ontology is an attempt to scrutinize our use of them. ${ }^{\prime \prime 1}$ This has the advantage of directing us away from perennially tempting misunderstandings whereby metaphysics would be concerned with a special class of "things" hidden from ordinary view, and perhaps demands some special "faculty" or "intuition" distinct from ordinary knowledge on the part of its practitioner. Geach's definition is functionally equivalent to the formula of Lash which has already been quoted: "[M]etaphysics is ... that branch of philosophy the logic of whose procedures focuses on analogical usage of unrestricted generality." ${ }^{\prime 42}$

Several aspects of Lash's account seem to worry Milbank, but should they? Thus, for example, Milbank chides Lash for assuming that the one cure for the historical tendency of metaphysicians to assume that their basic categories of reality pick out actual entities lies in insisting that metaphysics is concerned not primarily with being but with speech. Thus any philosopher, be it Aristotle, Kant or Wittgenstein, who has the correct negative perception of the non-substantive character of the categories must by the same token share the same positive construal of their status as "merely" linguistic (p. 44). However, a reading of Lash's 1982 article will reveal that he makes no such crude equation between the positions of the figures named, and that such alignments as are discerned are specified in different terms. But Milbank's characterization, though unfair, points to one of his concerns. Theology cannot allow philosophy any determination of the identity and status of the basic conceptual terms for construing reality, since theology, as Milbank understands it, must appropriate that task for itself.

Milbank offers a similarly questionable description of Lash's account when he claims that the latter expects from philosophical ontology a "neutral, 
universal metaphysical inventory of necessary grammatical categories," presupposing that the philosopher "can draw up a list of categorial presuppositions once and for all. ${ }^{43}$ It is difficult to see how anything like such a position can be attributed to Lash. Precisely by directing attention to the linguistic character of the conceptual tools we use to parse the totality of experience, any conception of ontology on Geach's lines will be alerted to the contingent and culturally-conditioned character of the ontological enterprise at every stage. Thus any determination of the concepts truly basic to all rational discourse will have to be a never-finished enterprise. In advocating a "grammatical" (in Wittgenstein's sense) understanding of ontological investigation, Lash could hardly have in mind a sort of complete and timeless account of realities impervious to the cultural and historical situatedness of its practitioner. How could it be so, when Lash cites with approval the following description of Wittgenstein? "In emphasizing the fluidity of the grammatical / material distinction, he was drawing attention to the fact that concept-formation-and thus the establishing of rules for what it does and does not make sense to say... is something that is always linked with a custom, a practice. ${ }^{\prime 44}$

Again, however, the misplaced philosophical concern on Milbank's part points to an underlying theological reflex, one which might be called loosely "postliberal." That is, what is really wrong with Lash allowing a philosophical ontology that essays a "universal" categorial scheme is that theology would have to "take prior account" of it. ${ }^{45}$ Because Lash sees in ontological concept-analysis an important critical check on theological language, Milbank apparently assumes that he has thereby given philosophy a kind of neutral, foundational role vis-à-vis theology; ontology would situate theology rather than the latter undertaking a fundamental revision of ontology in order to "effect our most basic and assumed perception of the world." ${ }^{\text {"6 }}$ What might Lash say to this? At least two sorts of retort seem ready to hand. On one level he can argue that the use of reasoned argumentation to tease out an array of the most basic terms used to construe the totality of our experience and probe their logic does not, on his understanding of the matter, contribute any sort of "neutral," "universal" ontological picture to which theology must then strain to accommodate itself. After all, it is the theologian who Lash imagines engaged in this enterprise in the first place. The procedures he envisions do not provide a ready-made, fixed and global metaphysical scheme, but rather aid in the task of formulating a plausible and selfconsistent conceptual language for relating God and world (in light of the sources and traditions of the faith) through a disciplined scrutiny of the logical interrelations and implications of the indispensable categories believers share in common with self-aware language-users in general.

To put it another way, Lash's picture of ontology-as-grammar need not, pace Milbank, present a covert philosophical foundationalism, but implies something rather more modest. It need not involve the production of a 
comprehensive "scheme," but it can bring to light logical weaknesses in the schemes implicit in religious speech or elaborated in theology, helping to insure that Christian claims are not patently nonsensical in light of some commonly appealed-to breadth of experience. And if Milbank might still balk at this, Lash could offer a second kind of reply, namely that Aquinas, too, would have to be deemed suspicious in Milbank's eyes. Aquinas's careful attention to the definitions and implications of metaphysical concepts, often appealing to basic shared philosophical understandings and always concerned with the rigor of rational argumentation-none of this is seen by Aquinas to involve some kind of alien "constraint" on theology, unless the constraint be that of rationality itself. The practice recommended by Lash is in fact no more "foundationalist" than that of Aquinas.

A glance at ST I/II q66 a5 ad4 suggests that Aquinas might be quite comfortable with Lash's portrayal of metaphysical analysis. Aquinas follows Aristotle in defining the habit of metaphysical insight as intellectual wisdom, highest of the three intellectual virtues (alongside intellect or understanding and science). Faced with the objection that intellect must be greater, since metaphysics draws conclusions based on indemonstrable principles known to the intellect, and knowledge of principles excels that of conclusions, Aquinas replies that grasping indemonstrable principles depends on understanding the definitions of the terms of which they are composed. ${ }^{47}$ But metaphysics or wisdom has the job of defining just those terms, namely "existent" (ens) and "non-existent," "whole," "part," etc. (all of which "follow upon ens" because their definitions all immediately incorporate the definition [ratio] of "existent"). Hence while in one sense the habit of metaphysics depends on the first axioms of the intellect, in another it judges and defends them by grasping their "rationes." The point is that Aquinas sees in metaphysical thinking something very much like philosophical scrutiny of those concepts which "cannot but be used ... in all rational discourse whatsoever."

\section{Milbank's Appeals to Aquinas}

The intention of the previous section was to suggest that Milbank's initial characterizations of the "grammatical" understanding of ontology are questionable, and his verdicts over-hasty. They do, however, reveal important currents in Milbank's thought. As the quote above about categories forming "our most basic ... perception of the world" suggests, Milbank immediately equates the determination of basic ontological concepts with setting the parameters of cognition itself. Hence his repeated accusation that Lash's scheme is not just a foundationalism but a kind of transcendentalism as well (p. 46, cf. p. 51). This, however, surely says more about Milbank's fixation on Kant than it does about Lash, especially since the latter does not seem to identify basic ontological concepts with the categorical conditions of perception. If Milbank's accounts of the position he rejects are indeed flawed in this way, it becomes all the more important to explore critically the reading of 
Aquinas which Milbank believes warrants such a rejection. This section will accordingly concern itself with the way Milbank tries to rule out the possibility of Lash's "grammatical" interpretation of analogy in Aquinas through appeals to Aquinas's own texts. Three sorts of consideration are adduced, but how convincing are the citations?

(i) Aquinas and the revealed names

Milbank begins by reminding the reader that Aquinas, following PseudoDionysius, assumes the ultimate source of the "names" for God explored in ST I q13 to be revealed scripture (p. 46). How then, he asks, could analogy have to do with the semantic range of certain words instantiated in their everyday ("secular") usage? ${ }^{48}$ But this question is answered as soon as asked. As has already been noted above, according to Lash the Christian language for God is indeed learned through the communal performance of scripture. The fact that the use and application of these namings is learned in the context of praise and prayer, guided by revelation, in no way conflicts with the fact that a semantic investigation of some of these terms (which are never simply invented but adapted for worship from more general contexts of usage) will reveal that they "cannot be said to be not literally applicable to God." Where is the contradiction?

(ii) Aquinas and the presupposed knowledge of God

Milbank follows up this comment with a consideration of the context of question 13. It is crucial, he argues, that that discussion of our names for God follows immediately upon Aquinas's account of how God can be known in this life (ST I q12 aa 11, 12,13). He characterizes the point of these earlier articles to be that "the vision of God in glory is dimly anticipated by some vision of God in his effects, consequent upon their participation in the divine esse" (p. 46). Therefore, he concludes, "analogy is predicated upon the metaphysics of participated being. ${ }^{\prime \prime 9}$ But the argument is hardly compelling. First, of course question 13 (in which analogy is discussed) follows question 12 because, generally speaking, how we name God follows upon how we know God. But this in no way implies that understanding the meaning of analogy as such and how it works depends upon the issue of how God is known.

To rehearse a point made above, how analogical predication works is one thing, in what situations it is applicable is another. The imagined issue here between Milbank and Lash is on one level merely terminological. If one defines the issue of analogy in Aquinas to be "how perfection terms like 'wise' can be shown to apply literally even to God," then you do indeed need an account of God as first cause and what kind of human knowledge we can have of this. But if one defines it to be "how literal (proper or nonmetaphorical) attribution is possible in cases where univocal predication of a term is ruled out," then everything said by McCabe, Burrell and Lash about 
analogy is perfectly understandable and defensible. The humdrum example Aquinas calls upon to illustrate what he means by analogy (usages of the adjective "healthy") should make it clear that analogy must first be a linguistic possibility before it can be appropriated for theological use. For this reason Milbank's conclusion, that analogy is "predicated upon" Aquinas's metaphysics, is true in one sense but not in any way that would invalidate Lash's approach. The latter is of course aware that the ontological presupposition of participative causality is the formal license to use perfection terms for God. ${ }^{50}$ But his basic point stands: the "way of analogy" in Aquinas neither substitutes for nor directly confirms the pedagogy of praise; it simply sheds an important light on the logical status of some of the language of praise, showing that its use in proper descriptions (and hence as premises for rational demonstrations) is not unintelligible.

Moreover, the passages of Aquinas Milbank cites do not support his description of natural knowledge of God in this life (p. $127 \mathrm{fn} .109$ ). To speak of a "vision" of God is quite misleading with regard to ST I q12 a13 ad1. There Aquinas indeed speaks of knowledge of God based on his effects, but in a number of places he specifies just what kind of knowledge is involved here, namely the paths of remotion and eminence, which in no way remove the cognitive barrier between human beings and proper knowledge of God (i.e., of the divine essence). At ST I q12 a11 ad4 he defines intellectual vision as possible only where the thing seen is present in the soul by its essence, a state of affairs describing the beatific vision but not (Aquinas always speaks in either/or terms here) our knowledge of God in this life, whether aided by grace or not. It might be thought that Milbank's quote from ST I q12 a12 ad2 ("God is known by natural knowledge through the images of his effects") is speaking of an "imaging" or reflection of God in creatures, but the word "images" simply translates phantasmata, and hence refers only to the image within the mind of the knower of some object of sense. This is the mind "imaging" the effect, not the effect "imaging" God. Finally, Aquinas does not, contra Milbank's suggestion, give any role in his discussion in question 12 of knowledge of God in this life to the participation of creaturely effects in God as their cause. That discussion occurs only in question 13 , where the issue is what names are suitable for God (a logically distinct matter, as has been argued above). Here he speaks only of the deficient participation of human intellects in God's perfect intellectual power, not of the participatory status of the objects of our intellects.

(iii) Aquinas and the three types of causality

The third and final argument from passages of Aquinas which Milbank brings against Lash is not so much tendentious as guilty of sheer confusion. He makes reference to ST I q4 a3 with the triumphant claim that "[h]ere is the text which confirms that one may speak of analogia entis in Aquinas and 
disallows [!] analogy as primarily a reflection on language" (p. $127 \mathrm{fn} .110$ ). He claims that here we have evidence that Aquinas can speak of univocal causes, equivocal causes, and analogical causes, with the latter referring to God as creator. Surely, Milbank argues, this shows that Aquinas's famous account of analogical predication as a kind of mean between univocal and equivocal predication is rooted in an ontological relationship between three types of causality? But the texts in question are surely being misread.

First of all, Milbank has seemingly missed the fact that Aquinas's entire discussion here draws upon a traditional two-fold distinction between kinds of agent-effect relationship, univocal and equivocal. According to Aristotle's theory, in biological generation the proximate cause of one member of a species is another member of the species, the parent. This is an instance of what came to be called in the scholastic tradition "univocal agency," because the effect produced (the offspring) is of the same kind as the cause. However, there is a more ultimate cause of biological generation, namely the sun, a celestial body; through the influence of the heat of its passage it is the universal cause of all particular instances of birth in the sublunary realm. The original context of the distinction between "univocal" and "equivocal" agency is thus the distinction between the causal properties of earthly and celestial bodies. Univocal agents produce their kind, exercising goodness in accordance with the essence of the species they are in, by producing more instances of the species; equivocal agents, the celestial bodies, cause lower bodies to engage in generation, but are acting not for the sake of the generated species but in accord with the genus "celestial body." By failing to advert to the technical character of this terminology, Milbank does not see that it involves a dualism which allows of no median term. An agent either produces another instance of its own species, or it does not; it is either univocal or equivocal.

This first mistake bears its fruit in Milbank's second confusion, whereby he assumes that "analogical agency" must be a third kind alongside univocal and equivocal. In fact, however, ST I q13 a5 ad1 shows that "analogical" is suggested by Aquinas as a better description of the non-univocal kind of causality; it is not a third type but an alternative naming of the second type. The reply to the first objection simply cripples Milbank's entire argument, because it makes clear that "analogical" agency is not a special case applicable to the God-creature relation; it refers to the case of any "universal" cause of an entire species, as for example the sun is of generables. It is true, as Milbank notes, that Aquinas (in ST I q4 a3) can speak of a "generic likeness" between the sun and generables which does not hold between God and creatures. The reason is that "body" is a genus shared between the celestial body and animal bodies, while "existent" is not a genus and thus cannot found a similar generic likeness between creator and creature. Rather, Aquinas calls the kind of similarity between God (as "ens per essentiam") and the creature as ("ens per participationem") "merely" an analogical likeness. But 
this does not ground a third kind of agency. Both the relation of sun to generables (with its "generic" likeness) and the relation of creator to creatures (with its lack of such a likeness) come under the common heading of non-univocal causality, traditionally called "equivocal." Aquinas sometimes follows the latter usage, but in question 13 he argues that because there is always some similarity, however tenuous, between agent and effect, "equivocal" should for the sake of accuracy be replaced by "analogical."

The unavoidable conclusion is that there are not, as Milbank imagines, three categories of causality (univocal, equivocal, and analogical), from which it immediately follows that the complex "paradox" he tries to construct whereby an analogical relation displays both more and less likeness than an equivocal one has no basis in Aquinas. More generally, his attempt to argue against Lash that these discussions somehow prove that ontological analogy is more basic in Aquinas than linguistic cannot even get off the ground.

On the one hand, Aquinas himself explicitly brings together the different kinds of agency and the different modes of predication in a way sharply distinct from Milbank's, showing that they belong to two quite distinct logical orders, and that there is no "reduction" of the linguistic to the ontological dimension. Aquinas's argument at ST I q13 a5 ad1 is that even though in predication the equivocal term (e.g., the dog star) must be "reduced" to the focal, univocal usage (the barking canine), in types of agency it is actually the equivocal cause to which the univocal cause is reduced, since the former as universal is prior. However, since the non-univocal cause does in some sense produce its like, it is better called analogical than equivocal. This terminological shift then sets up a neat move. Just as in predication every univocal term is reducible to the analogical (i.e., non-generic or transcendental) term "existent" (another way of saying that "existent is the first conception of the intellect"), so in agency all univocal agency (animal generation) is reducible to analogical agency (movement of celestial body).

On the other hand, the way Aquinas in this passage juxtaposes the two uses of the adjective "analogical" highlights the degree to which, arguably, its primary meaning is "linguistic" in both cases. While Milbank thinks that Aquinas, by using "analogical" to modify an entity ("agent") rather than a kind of word usage, has thereby revealed its truly "ontological" status in his thought, in fact the technical usage explained above suggests something quite different. As is etymologically obvious from the other terms with which Aquinas aligns "analogy," univocity, equivocity and analogy all concern "voces," words. To call an agent "univocal" or "analogical" in itself means nothing. The adjectives only make sense because, in the former case, the names of the cause and its effect are the same (human being generates human being), while in the latter the names differ. $\mathrm{ft}$ would seem to be the case, in sum, that Milbank has garbled his account of Aquinas in his eagerness to find a something that will "disallow" Lash's interpretation of analogy. 


\section{The Ontology Behind Analogy: Things as Signs of God?}

The first two stages in Milbank's overall argument about analogy (his general strictures on Lash's "grammatical" interpretation of metaphysics, and his use of passages of Aquinas to argue for the primacy of the ontological in analogy) have now been examined. The final aspect to be briefly discussed is his sketch of the kind of ontological framework which he believes underlies and articulates Aquinas's discussion of analogy. He says that "unless things themselves can be read as signs of God, names cannot be used analogically of God" because, for Aquinas, names stand for ideas in the mind which refer to things, and we can only grasp things through sense mediation. And for things to be signs of God must mean that "the divine perfections are remotely visible in created perfections - or rather ... to see a created thing as possessing any perfection is to grasp its faint conveying of a plenitude of perfection beyond its scope" (p. 47). This is obviously a more detailed version of the suggestions Milbank had made about Aquinas in "A Critique of the Theology of Right." The same sorts of consideration discussed above militate against it.

The main problem concerns Milbank's claims as to how things are "signs of God" for Aquinas. To return to the distinction discussed earlier between what a term (like "good") refers to when applied to God, and what human users can understand with regard to that application (the "mode of signifying" of the word), it is clear that Milbank wants to resist what he regards as too "agnostic" a reading of Aquinas. For that reason, he rejects the idea that any perfection we attribute to God can only be known by us in a creaturely mode, and not in the higher mode in which God possesses it. Instead, the passage quoted suggests that our "mode of signifying" in fact encodes, as it were, an inchoate but nonetheless actual experience of God's mode of perfection, an experience implicit within any experience of a creaturely perfection.

This picture fails to accord with Aquinas's actual discussions of the "mode of signifying." At ST I q13 a3 ad2, he explains why Pseudo-Dionysius insisted that even names of God like "good" and "wise" (which are not metaphors but literally true) must nonetheless undergo apophatic negation. This is because "what is signified through the name does not befit [non convenit] God according to the mode by which the name signifies, but according to a more excellent mode." (This is, note, a disjunctive proposition, and as such is characteristic of all Aquinas's discussions of this matter.) For this reason Aquinas can go on to say (ST I q13 a6) that perfection terms are primarily applied to God with regard to what they signify, but as regards their imposition or use by us, and their mode or manner of signifying, they properly apply only to creatures. And this is because (as was pointed out in the previous section) for Aquinas "the ratio which is signified by a name is the intellectual conception concerning the thing signified by the name" (ST I q13 a4); that is, the word signifies something only by means of signifying the language-user's conception of that thing. And human language-users have 
intellectual concepts which are subject to strict limitations, since human minds are equipped to grasp only things which are metaphysically composite and temporally situated (ST I q13 a1 ad2, ad3).

Only a failure to acknowledge or take seriously how Aquinas deploys this notion of the "mode of signifying" could allow Milbank to make the kinds of claims that he does about the cognitive relationship between creaturely perfections and divine perfections. In the sentence quoted earlier he begins by saying that "the divine perfections are remotely visible in created perfections." There is a kernel of truth in this, but the imagery is systematically misleading. For Aquinas, it is a fact that creaturely perfections are present in God in a more eminent fashion. We can indeed know that this is so, but this does not mean that we know them as they are in God, that is, we cannot know them as exemplified in God's unimaginable simplicity. What the perfection term signifies is more properly in God, but the only way we can use the word, and hence what we can actually understand, is only the creaturely exemplification of the perfection. Any tentative intellectual grasp we can attain is a matter of argumentative inference and the ways of remotion or negation, and this is what renders Milbank's language of "seeing" and "visibility" problematic. No amount of qualification by adjectives like "dim" or "inchoate" will relieve the fact that the language of vision itself can only be pickwickian in the context of Aquinas. In sum, we may know God inchoately through perceiving and understanding creatures, but this does not mean we are "really" also perceiving and understanding God in doing so.

If that first phrase of Milbank's is thus rendered dubious, the phrase immediately following ("to see a created thing as possessing any perfection is to grasp its faint conveying of a plenitude of perfection beyond its scope") must seem even more so. The claim involved lies at the heart of that revisionist interpretation of Aquinas's view of knowledge which, as was suggested above, Milbank combines with two other controversial positions (the "evacuation" of metaphysics by theology, and the ontologizing of analogy being discussed in this paper) to comprise his idiosyncratic portrait of Aquinas in "Truth and Vision." The epistemology which Milbank claims to uncover depends both on a reading of Aquinas's discussion of metaphysical knowledge of the first cause which construes that knowledge in terms of a kind of quasi-aesthetic perception or phenomenology, and on a more general thesis that for Aquinas any true knowledge of created things already implies some kind of grasp of their created status, and hence a knowledge of God. The arguments that Milbank mounts for this strange interpretation of Aquinas (an interpretation which had already appeared in outline in the 1986 paper, whereby knowledge of God and of creatures are co-implicated) would demand a lengthy discussion which cannot be undertaken here. But enough has been said to show that, on the topic of immediate concern, serious questions must be put to the ontology which Milbank deploys against Lash in his rival account of Aquinas's understanding of analogy. 
As has been pointed out, Milbank argues that analogy in Aquinas can gain traction only because it is always already implicated within a rich theological ontology. Lash, in contrast, is criticized for following McCabe and Burrell in supposedly trying to isolate a purely semantic moment within the logic of analogy as the key to its functioning. This is an exaggeration in itself because, as earlier argued, Lash indeed grasps the vital connection between analogy and ontology in Aquinas. But it will be recalled that Milbank from the beginning also rejected Lash's account of ontology (following Geach and MacKinnon) as conceptual analysis. He clearly intends his own full-blooded theological ontology to provide a better representation of what Aquinas must presuppose than Lash's impoverished, "merely formal" sort of metaphysics ("scarcely metaphysical at all," as he puts it). ${ }^{51}$ This obscure assertion that Lash's supposedly "formal" metaphysic cannot be true to Aquinas provides one final twist in Milbank's debate with him on analogy.

Milbank argues that there is within Aquinas a radical, if largely implicit, theological critique of Aristotle's philosophical metaphysics: the latter is confined to laying down a barren, abstract architecture of the timeless structure of finite beings "in general," while an ontology informed by revelation encompasses the full scope of being in its individual and temporal contingency and complexity. ${ }^{52}$ Milbank therefore calls philosophical metaphysics "merely architectonic," identifying it with that self-knowing of the Aristotelian first mover (which is abstract and hence deficient and "metaphysical") which must be radically deficient compared to "God's self-knowledge" (because the latter "is at once formal and material, and therefore exceeds the metaphysical") (p. 40). The language which appears here of formal versus material is Milbank's shorthand for a contrast upon which he lays heavy emphasis in "Truth and Vision," the contrast between the impoverished generality of metaphysics and the rich grasp of differentiated singularity which God (and revealed theology too, he thinks) enjoys. What is not apparent from his usage is that this contrast of formal and material does not spring from Aquinas at all; as is shown by the sentence which originally (in "Intensities") opened the paragraph but was dropped for the later book chapter ("Truth and Vision"), the language is part of the polemic against Lash, though it springs from a nearly complete misreading of his position..$^{53}$

It will be recalled that Milbank in 1986 had (by implication) severely criticized Lash's description of metaphysical inquiry as exploring the logic of certain indispensable concepts, roughly comparable to Wittgenstein's talk of philosophy as "grammatical." ${ }^{54}$ In his belated "rude" reply, Lash, could only greet with astonishment Milbank's accusation that metaphysics thus conceived as "conceptual scrutiny" led automatically to a fatal dissociation of the sphere of linguistic usage from the sphere of ontology. He responded:

This is not a "confinement" of ontology, or metaphysics, to "our use of language," detached from questions of participation in Being," but the 
reappropriation of an ancient tradition which understood the distinction between "formal" and "material" discourse; a distinction which has some affinity (I put it no more strongly) with that drawn, by Wittgenstein, between "grammatical" and "material" uses of language..$^{55}$

This invocation of formal vs. material discourse proved fateful, for in "Truth and Vision" Milbank decided to turn it against Lash. For, Milbank asks, can it not be shown that Aquinas must see in the truly theological ontology mediated by revelation a grasp of being which goes well beyond metaphysics? For the latter as "merely architectonic" is confined to laying down a "formal" or general architecture of being, one hampered by an empty and abstract concept of being as ens commune, while the former as "metaarchitectonic," sharing the divine apprehension, is alone able to do full justice to the instantiation of being at the individual and concrete level, and thus can merge the "formal" level of general category with the "material" level of particular, historical instantiation. But is this consideration not fatal to Lash's conception of a "grammatical" metaphysics, since that will involve just the kind of confined, "formal" ontology which Aquinas surpasses (pp. 40-41)?

The problem with this argument, beyond the dubiousness of the whole "architectonic vs. meta-architectonic" rivalry which Milbank posits between metaphysics and revealed theology, is that Lash never propounded the idea that metaphysics was "formal." His point was that careful attention to conceptual usages as a basic mode of ontological procedure is neither anachronistically attributed to Aquinas nor implicated in a dangerous dichotomization of the linguistic and the actual. For it was a philosophical commonplace, from centuries before Aquinas up to his own day, that an important distinction could and should be drawn between what is attributed to our ideas or words, and what is attributed to real things, though clearly both were mutually and complexly related. Thus there is indeed a kind of precedent in this ancient practice for Wittgenstein's warning philosophers against confusing descriptions of things with rules for speech. More importantly, how can the mere recommendation of conceptual scrutiny be chided by Milbank as flight from the realm of real ontology, when Aquinas himself can be understood as using it himself, and on the basis of a long-accepted distinction of levels of discourse?

But Lash made a critical mistake which opened the door to Milbank's misapprehension. In the crucial sentence, by seeming to place the "ancient" distinction between formal and material discourse in apposition to the Wittgensteinian distinction between grammatical and material uses of language, Lash fostered the illusion that "formal" must match up with "grammatical" (since in each case "material" is the other member of the conceptual pair). In fact, however, the ancient logical distinction, going back at least to Porphyry but no doubt familiar to Aquinas, renders speech about speech as an instance 
of material discourse, while speech about things is formal discourse.$^{56}$ But when Wittgenstein later comes to make his own distinction, similar to but apparently independent of the one made in ancient and medieval tradition, he reverses, in a way which no doubt seems more natural to modern ears, the position of the adjective "material": while speech about speech is "grammatical," it is now speech about real things which is called material. Led astray by this quite incidental carelessness in Lash's wording, Milbank could elaborate upon the misbegotten notion that Lash was advocating a merely "formal" metaphysics, indeed seizing the term itself as a stick to beat Lash with, but only on the basis of his own questionable rendering of Aquinas as theologically triumphing over the mere "formality" of metaphysical knowledge. In light of this finding, the conclusion of this last section must be that Milbank's attempt to find in Aquinas a theological ontology of being which exclusively enables analogical reference to God misfires in two ways: it finds no sound support in the Aquinas text, and it is at least partly reliant upon a supposed contrast with a Lashian account of metaphysics which more or less evaporates when one brings to light the terminological muddle upon which it is based.

\section{Conclusion: An Agnostic Aquinas?}

This article has had three goals: to delineate John Milbank's portrayal of Aquinas and track its emergence in tension with Nicholas Lash's rival account; to evaluate that portrayal by examining his use of Aquinas's texts; and to point out some areas in which Milbank's anti-Kantian project has probably shaped his portrayal. With regard to the first issue, the confrontation between Lash and Milbank over Aquinas and analogy can be summed up along the following lines. Milbank complains that for Lash (and, it might be added, McCabe and Burrell) analogy "involves (at least initially) merely a projection from the possibilities of words that possess implicitly a range beyond what we can presently grasp" (p. 47). But if the discussion above has any merit, then Milbank's complaint must really be directed against Aquinas himself. Perfection terms can "refer" to God literally because, ontologically, God contains all perfection eminently, but also because, semantically, some of our perfection terms have meanings which do not explicitly connote finitude. Nonetheless, we cannot know the perfection of God through the literally correct application of those terms, because even though the "ratio" signified by the word has no limit annexed semantically to it, the mode of signifying of human users of the word inevitably does involve such limitation.

When Milbank then says that this semantic range must have ontological guarantee, Lash can readily acknowledge this. But the metaphysical argumentation which supplies the formal warrant for literal predication is the one Aquinas speaks of as involving the ways of negation and eminence, not the quasi-phenomenology of God's "appearing" in creatures which Milbank 
devises. Milbank's final recourse is then to say that Lash's interpretation would result in an agnostic rendering of analogy, a quasi-Kantian position leaving the good of God absolutely unknown (p. 47). This, in effect, would be equivalent to the position of Maimonides rejected by Aquinas, where God is called good only as the cause of created goodness.

But this is mistaken. According to ST I q13 a2, Aquinas rejects the position of Maimonides for three reasons: first, it provides no rationale for why some words are used more than others of God (God causes stones, too); second, every attribute we ascribe to God would have to be understood by us as exemplified by God only in a secondary sense and not according to its primary or focal meaning (an animal exemplifies "health" primarily, while medicine is named "healthy" in a secondary sense, as causative of animal health); third, those who intend to praise God as "good" or "wise" clearly do not intend this to mean that God is not "really" good or wise, but is only the cause of creaturely goodness or wisdom. Hence, Aquinas offers a theory where names do indeed signify God's very essence, even as they fail to represent him ("sed deficiunt a repraesentatione ipsius"). This solves all three problems: only certain perfection terms, and not terms like "stone" will be used; the terms will be understood as applying primarily and properly to God, that is, God will be held to exemplify the perfection in the fullest degree; and the intention of worshippers will be thereby honored.

But what is crucial to note is that Aquinas's theory rectifies all three deficiencies of the Maimonidean theory without infringing in the slightest on the "agnosticism," the lack of proper knowledge of the divine essence, which is involved in the separation of thing signified from mode of signification. Indeed, the article's response to the second objection, which Milbank expressly refers to (p. 127 fn 113), shows just this in its conclusion: when we call God "living" we do not affirm his causing life in creatures but rather we signify the first cause of all creatures in whom life most properly preexists, although in a more eminent mode than can be understood or signified. What is important to Aquinas in our attributing some perfection to God is that we can know that our utterance is neither false nor merely metaphorical, and therefore that we can affirm that God is in no way foreign to that perfection, and that it cannot be lacking in him. But the price of this, as Lash properly notes (following Burrell), is that we simply cannot in this life rid ourselves of our own inability to understand the proper sense of such a perfection-term, but are limited to our understandings of deficient, creaturely exemplifications of the perfection. ${ }^{57}$ Thus Lash's reading of Aquinas stands: we can affirm correctly more than we can understand. We can know that our creaturely goodness, say, is a shadowy participation of God's goodness; but, contra Milbank, we do not and cannot know God's goodness by means of the participated goodness we affirm. With this conclusion, it would seem, all of Milbank's fundamental objections to the understanding of analogy in Aquinas developed by McCabe, Burrell and Lash have been answered. 
On the second issue (Milbank's exegesis), it is to be hoped that the extent and detail of this survey will be construed as an attempt to do justice to the admirable energy and imagination with which Milbank has resorted to the intricacies of Aquinas's own texts. That notwithstanding, the result has been consistently to question the cogency of Milbank's appeals to the medieval doctor, and the plausibility of his interpretations. But how can one account for the paradox here, that what seems such a wrongheaded approach to Aquinas could spring from the pen of one who surely must be accounted one of contemporary theology's most brilliant and creative figures? Given the present author's lack of expertise in Aquinas, and the very real possibility that he has gotten into a muddle trying to follow Milbank's intricate arguments, corrections and clarifications on both counts are surely to be expected.

However, another possibility lies in returning to the third intention of this article, namely to indicate some ways in which both the overall shape and some of the details of Milbank's Aquinas interpretation show the influence of a great hostility, not just to Kantian epistemology, but even to any position that seems in the vicinity of it, or might be construed as paving the way for it. It would certainly be possible to show in greater detail than has been attempted here how much of the distortion in Milbank's way of reading Aquinas, and his allergy to Lash's way of reading, can be attributed to the powerful gravitational field invisibly exerted by that overriding concern. But the characteristics already suggested would probably remain central: the rejection of any rationally discernible limitations to the human epistemic grasp of the divine; the denial of any distance between epistemological reflection and theological ontology; and the insistence on the theological possibility of intuitive vision into the truth, goodness and beauty of being. Wherever Aquinas's texts appear to point in a different direction, these imperatives block more straightforward readings. Speaking more generally, this anti-Kantian affect surely prompts the very attempt to locate an "arcane" Aquinas who has gone largely unnoticed by centuries of interpreters, an attempt which underlies many of Milbank's more forced interpretations. ${ }^{58}$

Indeed, these interpretations occur within a constraining systematic framework structured by philosophical verdicts not only upon Kant but upon Descartes, upon Suarez, upon Duns Scotus. Aquinas is for Milbank one of the last great witnesses to the one, true Christian ontology; turning away from him the mind of the West commenced its inexorable decline into benighted secularity and nihilism. But being "placed" within a narrative this way, the mind of Aquinas in its true depth comes to be known almost, so to speak, $a$ priori; the things he "must" really be saying, all appearances to the contrary, are determined in advance as the refusal of all that would come later. If Milbank's way of reading Aquinas is indeed guilty of some of the flaws attributed to it in the foregoing critique, might it not be due to a fixation upon later figures and disputes? To a dragging of Aquinas into arguments which are not, and could not have been his own? 
Only further discussion will be able to clarify how much of Milbank's conceptions about Aquinas can be sustained. Nor should it be forgotten that many of Milbank's ideas about metaphysics and theology might afford great challenges and insights even if the attempt to father them on Aquinas falters. But even though this article can only make a small contribution to a judgment of Milbank's project as a whole, given the weight placed upon the intricate connections between his claims (and those of "radical orthodoxy") and their alleged instantiation in some of the great figures of the Christian tradition, the grave interpretive deficits in the appropriation of Aquinas which this article has uncovered will have to be alleviated or shown to be products of misunderstanding, if they are not to raise disquieting questions about the viability of the entire "radical orthodox" stance.

Nor is the dispute over "radical orthodoxy" the only ground for further investigation of the Lash-Milbank exchanges. They also open a new window looking out upon very important and long-standing disputes about Thomas Aquinas and the nature of human knowledge about being and God. The issue, as the title of Milbank's chapter aptly suggests, is one of vision. For Milbank it is finally the fact that being can be seen, that all properly (Christianly) formed subjectivity is an incipient beholding of "what is" in its truth, which demands both the displacement of the metaphysical glance at limited being by theology's gaze into its boundless divine depths, and the refusal of any constitutive limit upon knowledge of God from the side of the human knower (as suggested by Lash's "grammatical" take on analogy). At one point Milbank testily declares that his position shows that "Jacques Maritain, (however much he has been sneered at) was absolutely right as against Gilson and others to claim that there is some inchoate temporal knowledge of the divine essence in Aquinas" (p. 31), later adding that this does indeed involve a recovery in a new key of the old idea of an "intuition of Being" (p. 51).

Such an intuition was precisely what MacKinnon had lost faith in, only to receive the reassurance of Lash that Aquinas had never believed in it either, and that analogy does not rely upon it. Thus a controversy older than Lash or Milbank was renewed. Is, for Aquinas, our access to the truth of being itself a matter, finally, of some kind of direct perception (even if reflectivelysituated, according to Milbank), or is it rather a matter of always tentative and indirect inference, never detachable from the limits in this life of our cognitive apparatus and its necessarily experimental venture? If Milbank's position roughly aligns him with a tradition going back to John of St. Thomas and extending through Maritain and Mascall, Lash's shows the marked influence of his masters MacKinnon and Lonergan, with Cardinal Newman hovering in the background. ${ }^{59}$ Does it need by now to be added that Kant is also a crux of this discussion?

To call up an even older but not unrelated dispute: Is, for Aquinas, the essence of God somehow glimpsed, in spite of everything, by the faithful 
even in this life, or are his repeated affirmations of our utter ignorance to be taken in their full rigor? Once again Milbank rejoins, intentionally or not, the trajectory of Maritain, Mascall and many others in their resistance to the more apophatic readings of Aquinas propounded by Sertillanges, Gilson, Victor White, Columba Ryan and David Burrell. ${ }^{60}$ Nor can Lash's sympathy with MacKinnon be ignored here; the latter's position on knowledge of God was complex and under continuous development, but his acid assessment of any glib optimism in theological epistemology was anchored not only in what he always took to be Kant's salutary insistence on the strict limits of human knowledge, but also in his suspicion that such easy approaches to the divine short-changed both the tragic predicaments of historically-situated human agents, as well as the depths of God's response in the mystery of the cross. (His startlingly scornful assessment of Mascall's approach to that mystery as "ultimately trivial and sterile" is thus perhaps not completely unrelated to the foregoing discussion. ${ }^{61}$ In sum, for Lash knowledge of the subsistent act of being which is God can only be that "dark knowledge" entangled in the living, evolving act of faith and its attentiveness to what calls from beyond the ineradicable limits of our perception and cognition. ${ }^{62}$ In this life, being is heard and not seen. What is ultimately at issue between Lash and Milbank is just this insistence on the tempering of our sight by an always greater nescience. Even so, as far as their dispute over Aquinas goes, it is no irony to say that Lash saw further.

\section{NOTES}

1 The founding texts are John Milbank, Theology and Social Theory (Oxford: Blackwell, 1990; second edition 2005) and John Milbank, Catherine Pickstock and Graham Ward (eds), Radical Orthodoxy: A New Theology (London: Routledge, 1999).

2 The two texts referenced involve treatments of Augustine by Milbank, Pickstock and Michael Hanby, and of Anselm by David Moss, as well as an apology for pre-Suarezian notions of revelation by John Montag. In addition to further work on Augustine by Milbank, Pickstock and Hanby, one might also mention Milbank's interpretations of Gregory of Nyssa and Meister Eckhart in Milbank, The Word Made Strange (Oxford: Blackwell, 1997), pp. 194-216 and pp. 45-48.

3 "Truth and Vision," in John Milbank and Catherine Pickstock, Truth in Aquinas (London: Routledge, 2001), pp. 19-59.

4 What eventually became the chapter "Truth and Vision" originally appeared as John Milbank, "Intensities" Modern Theology Vol. 15 no. 4 (October, 1999), pp. 445-497. The circumstances of its original composition will be elaborated upon below. In what follows, page references to the book version ("Truth and Vision") will be made parenthetically in the text. However, because many illuminating comments, especially those concerned with Lash, were dropped for that version, it will be necessary repeatedly to make reference to the original Modern Theology version as well. These will appear in footnotes as "Intensities," followed by the page number.

5 See the tributes by Nicholas Lash ("Donald MacKinnon: The Stuff of Legend," The Guardian, March 5, 1994) and by George Steiner ("Tribute to Donald MacKinnon," Theology, 98 [1995], pp. 2-9). For a bibliography up to 1980 see Brian Hebblethwaite and Stewart Sutherland (eds), The Philosophical Frontiers of Christian Theology: Essays Presented to D.M. MacKinnon (Cambridge: Cambridge University Press, 1982), pp. 239-248. See also Kenneth Surin, Christ, Ethics and Tragedy: Essays in Honour of Donald MacKinnon (Cambridge: Cambridge University Press, 1989). 
6 Nicholas Lash, "Ideology, Metaphor and Analogy," in Hebblethwaite and Sutherland, pp. 68-94; later collected in Nicholas Lash, Theology on the Way to Emmaus (London: SCM Press, 1986), pp. 95-119. Page references will be to the latter version.

7 Lash, "Ideology," pp. 106-114.

8 Lash, "Ideology," p. 106.

9 In 1941 MacKinnon could still insist on the centrality for theological knowledge of the analogy of being, referring enthusiastically to Penido's "invaluable treatise on the method of analogy." D. M. MacKinnon, "Revelation and Social Justice" in Malvern 1941: The Life of the Church and the Order of Society (London: Longmans, Green and Co., 1941), p. 83. He refers to the then widely respected Thomist study, Maurilio T.-L. Penido, Le rôle de l'analogie en théologie dogmatique (Paris: Vrin, 1931).

10 Lash, "Ideology," p. 107; citing Donald MacKinnon, "Metaphysical and Religious Language" [1954], in Borderlands of Theology (London: Lutterworth Press, 1968), p. 210.

11 Lash, "Ideology," pp. 109-110. He follows David Burrell, Aquinas: God and Action (London: Routledge \& Kegan Paul, 1979).

12 John Milbank, "'Between Purgation and Illumination': a critique of the theology of right," in Surin, Christ, Ethics and Tragedy, pp. 161-196; also collected (with some revision) in Milbank, The Word Made Strange, pp. 7-35. Page references will be to the latter, more widely available, version.

13 John Milbank, "A Critique of the Theology of Right," in The Word Made Strange: Theology, Language, Culture (Oxford: Blackwell Publishers, 1997), pp. 7-35; p. 9.

14 Lash had seen Burrell's understanding of Aquinas on analogy as very similar to that of the English Dominican Herbert McCabe, especially as delineated in the latter's "Appendix 4: Analogy" found in Thomas Aquinas, Summa Theologiae, vol. 3; Knowing and Naming God, Ia. 12-13 (London: Eyre \& Spottiswoode, 1964), pp. 106-107. Burrell himself refers appreciatively to McCabe several times in Aquinas.

15 Interestingly, Lash had been invited to chair the MacKinnon conference, but was at the time in the United States, working on the book that was to become Easter in Ordinary while a fellow of the Woodrow Wilson International Center for Scholars in Washington, D.C. See Nicholas Lash, "Renewed, Dissolved, Remembered: MacKinnon and Metaphysics," in New Blackfriars (November 2001), p. 497; now available in Lash, Theology for Pilgrims (Notre Dame: University of Notre Dame Press, 2008); and Lash, Easter in Ordinary (Notre Dame: University of Notre Dame Press, 1988), p. ix.

16 Milbank, "Theology of Right," pp. 9-10.

17 Ibid., p. 13.

18 Ibid., p. 9.

19 Ibid., p. 9.

20 Ibid., p. 13.

21 Ibid. p. 13 and p. 33 fn. 15. For a brief standard treatment see Jan Pinborg, "Speculative Grammar" in Norman Kretzmann et al. (eds), The Cambridge History of Later Medieval Philosophy (Cambridge: Cambridge University Press, 1982), pp. 254-269.

22 In the discussions of Aquinas which follow and for the rest of this article, citations of his works will be made parenthetically in the text. The following abbreviations will be used: $\mathrm{ST}=$ Summa theologiae; $\mathrm{SCG}=$ Summa contra gentiles; In PA = Sententia super Posteriora analytica; $\mathrm{QDP}=$ Quaestiones disputatae de potentia $;$ In BDT $=$ Expositio super librum Boethii De trinitate; In $\mathrm{M}=$ Sententia super metaphysicam; In Sent = Scriptum super libros Sententiarum. In most cases standard English translations have been followed, but in several instances silent emendations have been made where it seemed appropriate and warranted by the Latin. It should be noted that the original Milbank article "Intensities" contained a very large number of confusing or mistaken reference notations to the Aquinas texts; some were corrected for the book edition, but many were not. In what follows I have silently corrected obviously incorrect reference data. Some special terminological issues should also be mentioned. The term "epistemology" is used throughout in a broad sense to mean a philosophically or theologically informed theory or account of human knowledge; it is not intended in Milbank's more limited usage, where it tends to signify an intellectual pursuit specifically linked to the assumptions of modernity. The term "revealed theology" will be used to refer to what Aquinas calls sacra doctrina or "holy teaching," as opposed to that account of the divine which can be given in the sphere of philosophical theology or metaphysics. The 
verbal form of Aquinas's esse will be stressed by consistently translating it "act of being"; the correspondingly nominative form of ens will be reflected in the translation "existent."

23 Milbank, "Theology of Right," p. 13.

24 Paul Vincent Spade, "The Semantics of Terms," in Cambridge History of Later Medieval Philosophy, p. 188.

25 Milbank, "Theology of Right," p. 33 fn 15.

26 lbid.

27 Ibid., p. 15.

28 Ibid., pp. 15-16.

29 Ibid., pp. 13-14.

30 Nicholas Lash, "Not Exactly Politics or Power?," Modern Theology, Vol. 8 no 3 (July 1992), pp. 353-364.

31 Ibid., p. 361.

32 See, for the first, John Milbank, “Theology without Substance: Christianity, Signs, Origins," Literature and Theology Vol. 2 (1988), pp. 1-18, 131-52 at pp. 144-145; now available in Milbank, Word Made Strange, p. 110. For the second, see Milbank, Theology and Social Theory, pp. 247-248. For the third, see John Milbank, "Can a Gift be Given? Prolegomena to a Future Trinitarian Metaphysics," Modern Theology Vol. 11 no 1 (January 1995), pp. 119-161 at pp. 143-144.

33 For the reason mentioned in footnote 22 above, Milbank sometimes uses the term "gnoseology" in his discussions of Aquinas on knowledge, in order to avoid the bad connotations he associates with the term "epistemology."

34 John Milbank, "Only Theology Overcomes Metaphysics," New Blackfriars, Vol. 76 (1995), pp. 325-342. Revised version in Milbank, Word Made Strange, pp. 36-52.

35 See Laurence Paul Hemming (ed), Radical Orthodoxy?: A Catholic Inquiry (Aldershot: Ashgate Publishing Ltd, 2000), p. 3.

36 Nicholas Lash, "Where Does Holy Teaching Leave Philosophy? Questions on Milbank's Aquinas," Modern Theology Vol. 15 no. 4 (October 1999), pp. 433-444 at p. 433.

37 Ibid., pp. 436-437.

38 Milbank, "Intensities," p. 445.

39 Milbank, "Intensities," pp. 446-447.

40 Milbank, "Intensities," p. 478.

41 Peter Geach, "Symposium: On What There Is," in Freedom, Language and Reality, Aristotelian Society Supplementary Volume 25 (London: Harrison, 1951), p. 134. Cited in Lash, "Where Does Holy Teaching," p. 434.

42 Lash, "Ideology," p. 106.

43 The first quote comes from the earlier version of the chapter ("Intensities"), where it appears on p. 471. The second is found in the book version on p. 44.

44 Lash, "Where Does Holy Teaching," p. 442 fn 32, quoting Ray Monk, Wittgenstein: The Duty of Genius (London: Jonathan Cape, 1990), p. 468.

45 Milbank, "Intensities," p. 471.

46 Milbank, "Intensities," p. 470.

47 As he puts it in his commentary on Aristotle's Posterior Analytics, "[T]here are some immediate propositions whose terms are not known by everyone." (In PA I.5) The lack of knowledge here is not necessarily mere ignorance of the word's standard usage, but also applies to cases where there is wanting the scientifically precise definition of the term which would render the immediacy of the proposition evident. That is, Aquinas "distinguishes between knowing the signification of a term ... and knowing the real definition associated with the term." Scott MacDonald, "Theory of Knowledge," in Norman Kretzmann and Eleonore Stump (eds), The Cambridge Companion to Aquinas (Cambridge: Cambridge University Press, 1993), p. 190 fn 32.

48 Cf. Milbank, "Theology of Right," p. 16.

49 The echoing of MacKinnon is perhaps intentional: "The analogy of the scholastics was fundamentally ontological," demanding an affirmation of "analogically participated being." MacKinnon, "Metaphysical and Religious Language," pp. 209-210. The point, at any rate, is clear: Lash's "correction" of MacKinnon's metaphysical understanding of analogy is misbegotten. For Milbank, MacKinnon's dubious Kantianism may have made him doubt the possibility of analogy, but at least he properly understood what he was doubting. 
50 Lash, "Ideology," pp. 111-112.

51 Milbank, "Intensities," p. 494 fn 98.

52 Once again, an analysis and assessment of this claim, part of the claimed "evacuation" of metaphysics by theology, cannot be attempted here.

53 Milbank, "Intensities," p. 467.

54 Milbank, "Theology of Right," pp. 13ff, cf. Lash, "Ideology," pp. 108ff.

55 Lash, "Where Does Holy Teaching," pp. 436-437.

56 The basic distinction in question (i.e., that between "names which designate extra-linguistic entities and names which designate other names") was formulated by Porphyry as names of first imposition versus names of second imposition, was picked up by Boethius, was later applied in a related sense by Avicenna to posit a similar distinction in natural signs (touching off later medieval discussions about "first and second intention"), and was eventually incorporated into the later scholastic theory of suppositions as a distinction between formal and material supposition. See William Kneale and Martha Kneale, The Development of Logic (Oxford: Oxford University Press, 1962), p. 195, pp. 229-230, pp. 252-325.

57 Lash, "Ideology," p. 112.

58 Milbank began the chapter "Truth and Vision" with the hermeneutical claim that the structured argumentation comprising the bulk of Aquinas's writing is more for the refutation of error, and is not the place wherein to discern his true position: "[T]he arcanum of his teaching lies not here," and indeed can obscure the brief and often cryptic utterances wherein Aquinas's most profound positive insights are to be found (p. 20). Milbank evidently understands his chapter as an exercise in recovering the arcane but genuine position of Aquinas so regularly missed by other commentators (including most particularly, as the earlier version of the chapter made clear, Nicholas Lash).

59 Milbank's attempt to read Aquinas through the "semiotic" epistemology of the seventeenth century Thomist commentator John of St. Thomas goes back to his 1988 essay "The Linguistic Turn as a Theological Turn" (originally entitled "Theology Without Substance: Christianity, Signs, Origins"), now available in Milbank, Word Made Strange, pp. 84-120. See especially p. 100 and pp. 115-116 fn 43. There Milbank also claims that it was Maritain's use of John of St. Thomas which enabled his "rebuttal of Maréchal and the 'transcendental turn'," referencing Maritain's major epistemological treatise Distinguish to Unite or the Degrees of Knowledge trans. G. B. Phelan (London: Bles, 1959). The Anglican theologian Eric L. Mascall in his widely read books $\mathrm{He}$ Who Is (1943, second edition 1966) and Existence and Analogy (1949) follows Maritain in affirming an intuition of being. With regard to the names mentioned on the other side, Lash began his scholarly career as an expert on Cardinal Newman. MacKinnon's rejection of any intuition of being was, of course, the point of departure for the entire dispute between Lash and Milbank which has been under discussion here. As for Lonergan, note Lash's sharp reaction to "the three sentences which Milbank deems [in "Theology of Right"] sufficient to dispose of" Lonergan's large, difficult and brilliant study of the "interior word" in Aquinas, Verbum (1967, originally a series of articles from 1946-19499). See Lash, "Where Does Holy Teaching," p. 436. Milbank's response to this chastisement was symptomatic: a slightly more elaborated repetition of his earlier judgment, bolstered by an undifferentiated cluster of scattered references to Lonergan, and encompassing all of a single paragraph. See Milbank, "Intensities," p. 472; "Truth and Vision," pp. 45-46. Lonergan's entire theological-epistemological project struggled against any model of knowledge as "taking a look"; Milbank predictably excoriates his "hostility to intellectual vision." With regard to the underlying issues at stake, Milbank's and Lonergan's contrasting evaluations of John of St Thomas are significant, and would repay further study. From Lonergan's perspective, John of St. Thomas's view of the interior word is actually more Scotist than Thomist in orientation. See the previously unpublished material in the appendix to Lonergan, Verbum: Word and Idea in Aquinas [Collected Works of Bernard Lonergan, vol. 2] (Toronto: University of Toronto Press, 1997), pp. 246ff. On the more general topic of Lonergan and Milbank, such brief verdicts as he has rendered here and there on Lonergan's massive and profound explorations are noteworthy only for their contemptuous offhandedness. Unfortunately, it must be said that we still await a genuine engagement by Milbank with this important figure.

60 The question of Thomas's precise position on quidditative knowledge of God in this life has accumulated a large literature. One starting point, with many references to earlier literature, 
might be John Wippel, The Metaphysical Thought of Thomas Aquinas (Washington, DC: Catholic University of America Press, 2000), pp. 502-542. Note especially footnote 91 on p. 526, where Wippel indicates some of the back-and-forth between Sertillanges, Maritain, and Gilson. For a useful orientation to one aspect of the English discussion, involving Mascall, Victor White and others, see Fergus Kerr, "'Real Knowledge' or 'Enlightened Ignorance': Eric Mascall on the Apophatic Thomisms of Victor Preller and Victor White," in Jeffrey Stout and Robert MacSwain (eds), Grammar and Grace (London: SCM Press, 2004), pp. 103-123.

61 D. M. MacKinnon, "Some Notes on Kierkegaard" [1956], in Borderlands, pp. 121-128 at p. 126.

62 Lash, "Ideology," p. 114. 